\title{
Implementation of Complete Systematic Land Registration Program in the City or District Of Ex-Residency Besuki (Study on the Implementation of Complete Systematic Land Registration Program in 2017 until 2019)
}

\author{
Faqih Sunni S. ${ }^{1}$, Tunggul Anshari SN. ${ }^{2}$, Supriyadi ${ }^{3}$ \\ ${ }^{1,2.3}$ Master Study Program of Notary, Faculty of Law, Brawijaya University, Indonesia \\ Faqihsunni@gmail.com
}

\begin{abstract}
Land has a very important role important in human life, because land is always closely related to the scope of everyday society, whether it is used for housing, farming, or conducting business activities. The existence of land has a dual function, namely as a capital asset and social asset. Therefore, to provide comfort and security to the owners and rulers of a field of land, legal land registration is very important to be carried out by the community. Thus, to make it easier for the community to obtain legal certainty, the ATR / BPN (Agrarian and Spatial Planning / National Land Agency) Institution established a program called Complete Systematic Land Registration (PTSL) which is carried out simultaneously throughout Indonesia. This study will discuss how the implementation of the Complete Systematic Land Registration Program (PTSL) in 4 (four) Ex-Residency Besuki Districts. By using an empirical juridical approach to study the applicable legal provisions and what happens in the reality of society, then it is analyzed using SWOT analysis and the effectiveness theory approach according to Soerjono Soekanto, who argues that the effectiveness of a law is determined by 5 factors, namely, law enforcers (those who apply the law) means and facilities that support law enforcement, society, and community culture. Data collection techniques used interviews and documentation. The results showed that the implementation of PTSL in 4 (four) Districts of the Former Residency of Besuki was effective in terms of law factors and facilities and infrastructure that support law enforcement. The implementation of PTSL in 4 (four) Ex-Besuki Districts was less effective in terms of Law Enforcement Factors, Community Factors, and Cultural Factors.
\end{abstract}

Keywords

implementation; policies or efforts of BPN land registration

\section{Introduction}

Land has a very important role in human life, because land is always closely related to the scope of everyday society, whether it is used for housing, farming, or conducting activities. The existence of land has a dual function, namely as capital asset and social asset. Therefore, to provide comfort and security to the owners and rulers of a field of land, hence, legal land registration is very important to be carried out by the community. Thus, to facilitate the community in obtaining legal certainty, the government has issued Government Regulation Number 24 of 1997 concerning land registration. There are 4 main reasons for the making of Government Regulation Number 24 of 1997 concerning Land Registration, as well as those that have been created in general, namely: 
1. The role of the fulfillment of various needs will increase, both as a place of residence and for business activities. Regarding with that there will also be an increase in the need for support to ensure legal security in the field of defense;

2. The land registration which has been held based on Government Regulation No. 10 of 1961 has been for more than 35 years hasn't given enough results yet. From around 55 million land fields who qualify for registration, In fact, more than 16.3 million fields have been registered;

3. The obstacles in the implementation of land registration are located in budget shortages, tools and power, fields which are large and scattered in large areas, and most of its ownership is not supported by evidence that is easy to obtain and can be believed in truth;

4. The legal provisions for the base of implementation are thought to be insufficient to provide the possibility to carry out land registration in a short period of time with more satisfying results.

Kind of land registration are divided into two, namely the systematically and sporadic land registration. In a systematic land registration that described in Article 1 Number (10) Government Regulation Number 24 of 1997 concerning land registration, which means systematic land registration is land registration activities for the first time which were carried out simultaneously covering all objects land registration Those that have not been registered in the region or areas of a village or sub-district. In this case, the National Land Agency establishes a Complete Systematic land registration program (PTSL) in 2017 in all regions of Indonesia, namely 4 (four) Former Besuki Regencies, those are Bondowoso Regency, Jember Regency, Situbondo Regency, and Banyuwangi Regency.

This PTSL program has a very big and positive effect on the community, especially the community in the middle to the bottom, because with this program, people can register their land with free tanahnya for a small fee or even free of charge, compared to sporadic registration which costs more expensive management and the issuance of the certificate requires a relatively longer time. Pmanagement of land registration that is carried out with PTSL, announcements of physical and juridical data and legalization only requires a 14 (fourteen) days. While sporadic land registration (Individuals) takes 60 (sixty) days.

Systematic land registration program activities in all cities / regencies throughout the residency of Besuki, in 2017 until 2019 in order to run effectively, certainly need to be supported by good quality Human Resources, namely the National Land Agency of each district has expert staff and the elected committees must be good, the facilities and infrastructure in PTSL activities must be fulfilled, as well as support from the community. However, in reality PTSL activities in 4 (four) districts of the Former Besuki Residency have various obstacles, which have resulted in the target of issuing certificates which should have been completed by the end of the Complete Systematic Land Registration program (PTSL). Become obstructed due to various factors. One of them is that there are several problems that arise in the PTSL (Complete Systematic Land Registration) program in cities / regencies around the residency of Besuki which have resulted in several certificates not being issued and also a lack of public awareness of the importance of the Complete Systematic Land Registration (PTSL) program. 


\section{Review of Literature}

The understanding of land registration is also included in the Laws and Regulations, namely in Article 1, level (1) Government Regulation Number 24 of 1997 regarding land registration. What is meant by land registration is the level of activities carried out by the government on an ongoing basis, continuous and regulated, including collection, management, bookkeeping, and presentation and maintenance of physical and juridical data, in the form of maps and lists, regarding the fields of land, and apartment units, including the issuance of a certificate of proof of their rights for a parcel of land which already have rights and rights to house / apartment units as well as certain rights that impose. Land registration objectives are also regulated under Article 1 Level (3) Government Regulation Number 24 of 1997 regarding land registration namely to provide legal certainty and legal protection to holders of rights over a land parcel, provide information to interested parties, and to maintain orderly land administration.

The policy of resolving land conflicts often forgets the most fundamental issue which is the recognition of land rights that can be enjoyed by the people. Whereas the Government is obliged to restructure and prioritize policy instruments in order to guarantee land and natural resource management that is coherent with the development agenda. Development must consider environmental preservation, or in other words maintain environmental balance (Kholil, 2019). Government is not built to serve its own needs, but aims to serve the needs and interests of the community and create conditions that allow each member of the community to develop their abilities and creativity to achieve common goals (Perdana, 2019).

Land registration issues are listed in Article 2 of Government Regulation Number 24 of 1997 regarding land registration such as simple principles, safety principles, affordable principles, current principles, and open principles. Implementation of Complete Systematic land registration (PTSL) consists of PTSL objects, Human Resources, namely selected PTSL committees, and stages of PTSL activities such as planning, location determination, preparation, formation and appointment of an Adjudication committee and a task force, counseling, collecting physical data and juridical data, researching juridical data to prove rights, announcing physical data and juridical data and ratification, confirmation of conversion, recognition of rights and granting of rights, bookkeeping of rights, issuance of certificates of rights and granting of rights, bookkeeping of rights, issuance of certificates of land rights, and the last stage, namely documenting and submitting the results of activities and reporting.

The success of implementing the Complete Systematic land registration program can be measured by looking at the effectiveness or failure of the activity. Effectiveness means the effectiveness effect of success or efficacy / efficacy, discussing the effectiveness of the law is certainly inseparable from analyzing the characteristics of the two related variables, namely the characteristics / dimensions of the target object used. ${ }^{1}$ MAccording to Soerjono Soekatto, whether it is effective or not a law is determined by 5 (five) factors, namely $:^{2}$

a. His own legal factor (Law)

b. Law enforcement factors, namely the parties who shape and apply the law

c. Facilities factors or facilities that support law enforcement

d. The public factor, which is the environment where the law applies or is applied

\footnotetext{
${ }^{1}$ Salim,H.S. dan Erlies Septiana Nurbani, Penerapan Teori Hukum Pada Penilitian Tesis dan Disertasi, Rajawali Pers, Jakarta, 2013, hlm. 375

${ }^{2}$ Soerjono Soekanto, Faktor-Faktor yang Mempengaruhi Penegakan Hukum, PT. Raja Grafindo Persada, Jakarta, 2008, hlm. 8
} 
e. Factors of culture, which are the results of works, creations, and feelings that are affected by the audience

The five factors are one and the same, because they are the essence of law enforcement, as well as a measure of the effectiveness of law enforcement. ${ }^{3}$

\section{Research Methods}

This research uses an empirical juridical approach, which examines the legal provisions that apply as well as what happens in the realities in society. The data obtained was based on the results of interviews with respondents determined by the researcher, namely the Head of the Land Office of Bondowoso Regency, Jember Regency, Situbondo Regency and Banyuwangi Regency, as well as the documentation obtained from the 4 (four) District Land Offices. The results of the study were then analyzed using a SWOT analysis, there were 4 elements, namely strengths and weaknesses for the former Besuki (Internal) Land Office as the implementer of the Complete Systematic Land Registration (PTSL) program. also elements of opportunities, and threats in carrying out the activities of Complete Systematic land registration (External). Then, it is linked to Soejono Soekanto's theory of legal effectiveness, by looking at 5 factors, namely law, law enforcers (those who apply the law) the means and facilities that support law enforcement, society, and culture.

\section{Results and Discussion}

\subsection{Complete Systematic Land Registration Program in Bondowoso Regency, Situbondo Regency, Jember Regency and Banyuwangi Regency}

PTSL activities are carried out based on the Regulation of the Minister of Agrarian and Spatial Planning / Head of the National Land Agency Number 6 of 2018 concerning Complete Systematic land registration. The government implements a Complete Systematic land registration program (PTSL) because this program can create a country that is safe in the field of land by providing legal certainty guarantees of land rights. Furthermore, the aim of holding a complete systematic land registration program (PTSL) is to provide guarantees for legal certainty and legal protection of land rights to the community in a definite, fast, safe, fair and equitable manner, so as to increase the prosperity of the community and to reduce and prevent the occurrence of land rights conflict or land dispute. Isnaini (2020) stated that Land disputes and conflicts are complex and multidimensional problems. Therefore, efforts to prevent, handle and resolve must take into account various aspects, both legal and non-legal. Often the handling and resolution of land disputes and conflicts is faced with dilemmas between different interests that are equally important. The PTSL implementation activities carried out by the Land Office of Bondowoso Regency, Jember Regency, Situbondo Regency, and Banyuwangi Regency are carried out through several stages guided by Ministerial Regulation Number 6 of 2018 concerning Complete Systematic land registration, as follows:

\section{1) Planning}

The Land Offices in Bondowoso Regency, Jember Regency, Situbondo Regency, and Banyuwangi Regency carry out planning in advance as an initial stage of PTSL

\footnotetext{
${ }^{3}$ Aan Andrianih, Efektivitas Undang-Undang Nomor 1 Tahun 1965 tentang Pencegahan Penyalahgunaan dan/atau Penodaan Agama terhadap Kerukunan Beragama, Jakarta, Tesis FH UI, 2012, hlm.99
} 
implementation, such as determining the location of PTSL, preparing a budget, forming Human Resources (Adjudication Committee) from the Land Office.

\section{2) Determination of Location}

Bondowoso District Land Office determines the location based on 3 factors, such as the estimated number of fields that have been recorded in a village, the number of fields that have been certified, there are several villages that independently apply to become PTSL participants. The Jember Regency Land Office determines the location of the village that submitted itself through a written request, then the Head of the Jember Regency Land Office will see the progress of the existing targets. If the request from the village exceeds the target set by the Government, the Jember Regency Land Office will make a selection taking into account the data owned by the village, such as village administration (Block map, cluster $\mathrm{C}$ map, and village information), and the percentage of the community in paying Land and Building Tax is classified as high or low. If the level of community tax payments in the village area is high, the community's awareness of the legal certainty of the land they control will also be higher. Vice versa.

In determining the location, the Land Office of Situbondo Regency in 2017 was carried out by appointing each village selected as the location for the complete systematic land registration (PTSL), then based on the experience of time, in 2019 there was a change in the PTSL pattern. One of the changes is to provide guidance to the village so that there are no obstacles in the implementation of PTSL in the future.

The Land Office of Banyuwangi Regency will determine the location based on the results of a field survey conducted by the special team of the Banyuwangi Regency Land Office. Villages that were selected as locations for the Complete Systematic land registration program are villages that have complete administration such as data readiness village data in the form of village $\mathrm{C}$ lists, village landscape maps, Village Block maps, List of Tax \& Payment Assessment ( Daftar Himpunan Ketetapan Pajak \& Pembayaran / DHKP) Land and Building Tax (Pajak Bumi dan Bangunan / PBB).

\section{3) Preparation}

The stages of preparation activities carried out by the Land Office of Bondowoso Regency, Jember Regency, Situbondo Regency and Banyuwangi Regency are based on Article 9 of Ministerial Regulation Number 6 of 2018 concerning Complete Systematic land registration by preparing:

1. Facilities and infrastructure: stationery, blanks, printers, computers, while those covered by the Land Office are paper, ink, and printer cartridges.

2. Human Resources: Human resources from the Land Office and PTSL village officials must be properly prepared, because this is one of the strong foundations so that the implementation of PTSL runs in an orderly manner..

3. Coordination with government officials with the aim that the PTSL program can be carried out smoothly and all people in the area can find out about the PTSL program.

\section{4) Establishment of the Adjudication Committee and Task Force}

The number of adjudication committees and task forces in the Complete Systematic land registration program (PTSL) were formed by the Head of the Bondowoso Regency Land Office, namely in 2017 there were 5 teams, in 2018 there were also the same number of PTSL teams, namely 5 teams, while in 2019 there were 3 team assigned to PTSL activities in Bondowoso Regency. 
The Head of the Jember Regency Land Office formed a PTSL team from 2017 to 2019 total 6 (six) PTSL teams, of which 1 (one) team has 5 (five) to 6 (six) members. The formation of 6 PTSL teams is the maximum recommendation that has been set by the Head of the Jember Regency Land Office.

The Head of the Land Office of Situbondo Regency from the beginning of PTSL activities in 2017 to 2019, formed 4 teams which in each team were divided into 15 members. The division of the team by the Land Office in each city or district varies according to the authority of the Head of the Land Office in each district or city. The distribution of the number of PTSL teams is usually seen from the target for issuing land certificates (Sertifikasi Hak Atas Tanah / SHAT), the more teams that are formed, the more targets for the issuance of land certificates.

The number of adjudication committees and task forces in the Complete Systematic land registration program (PTSL) were formed by the Head of the Banyuwangi Regency Land Office, namely in 2017 - 2019 there were approximately 5 teams.

\section{5) Counseling}

Counseling activities are carried out by each Land Office of Bondowoso Regency, Jember Regency, Situbondo Regency and Banyuwangi Regency. The information conveyed during outreach activities is all activities regarding the Complete Systematic land registration program (PTSL), starting from the initial stage of activities regarding village boundary markers, fees, to the end of the PTSL program, explaining the importance of having a land certificate, etc. based on Article 16 of Ministerial Regulation Number 6 of 2018 concerning Complete Systematic land registration. At the end of the counseling activities, the Land Office of Bondowoso Regency, Jember Regency, Situbondo Regency, and Banyuwangi Regency gives time to the people who come to ask questions or provide suggestions, this is expected so that the community will be more understand and open if something is on their minds.

\section{6) Collecting physical data and juridical data}

To obtain physical data, the Physical Task Force $(S A T G A S)$ in each district measures the land parcels to be mapped. The obligation to put up and maintain boundary markers is intended to avoid disputes or disputes over land boundaries with owners of land parcels that are bordering in the future. The boundary mapping is carried out by landowners and landowners who are bordering on a contradictory basis or often referred to as the Delimitation Contradictory principle.

The initial activity carried out by the juridical task force in collecting juridical data was collecting data by the village committee for initial data collection on PTSL participants or applicants, then the juridical task force assisted by the village committee collected administrative requirements, including :
a. Application form that has been filled in and signed by the applicant or his attorney with a stamp
b. Power of attorney if authorized
c. Photocopy of Identity Card (KTP)
d. Photocopy of Family Card (KK)
e. Photocopy of PBB Payable Tax Return (SPPT)
f. Pledge of rights (sale and purchase, grant, inheritance, or other documents) 
7) Research on juridical data to prove rights

Juridical data research for bookkeeping rights is carried out after the physical and juridical data collection activities, by examining the suitability of juridical data (completeness of PTSL participant or applicant files) with physical data (measurement results of mapped land parcels), as well as the legal relationship between the applicant and the land used requested. If during the land inspection process, the juridical task force and the village committee find a mismatch between the physical data and the juridical data, the juridical task force and village committee will return the applicant's or PTSL participant's files to be completed first.

\section{8) Announcement of physical data and juridical data and its validation}

The announcement of physical data and juridical data is carried out for 14 working days in accordance with Article 24 Number (2) of Ministerial Regulation Number 6 of 2018 concerning Complete Systematic land registration with the aim of fulfilling the principle of publicity in proving land ownership. During this period, anyone who feels that there is an interest in the announcement of physical and juridical data can file an objection to the PTSL Adjudication Committee which has legal consequences as long as there is no agreement between the right holder and the interested person, then the problematic field object data will not be included in cluster 1 but categorized into cluster 2 , so the land certificate from the right holder cannot be issued. This is in accordance with Article 29 Number (1) of Ministerial Regulation Number 6 of 2018 concerning Complete Systematic land registration.

\section{9) Confirmation of conversion, recognition of rights, and granting of rights}

Physical Data and Juridical Data that have met the requirements to issue a certificate of land rights, an Official Report on Physical Data and Juridical Data is made, and the Chairperson of the PTSL Adjudication Committee in Article 26 of Ministerial Regulation Number 6 of 2018 concerning Complete Systematic land registration follows up with:

a. Confirming the conversion to ownership rights in the name of the last right holder, for land parcels where the evidence is complete and whose written evidence is incomplete but there are witness statements or statements concerned, and provide notes without or with objection (not to court / in process at court with / without confiscation of guarantee) on the Treatise of Juridical Data Research.

b. Establishing recognition or affirmation as Property Rights, for areas of land whose proof of ownership does not exist but has been proven by the fact of physical mastery for 20 (twenty) years continuously including its predecessors, and give notes without or with a record of objections (not to the court / is being processed in court with / without bail) in the Minutes of Judicial Data Research.

c. Propose a decision to grant rights, for land parcels which are State land by proposing collectively to the Head of the Land Office using the Proposed List of Granting Property Rights or Building Use Rights (DI 310) and attaching the Treatise of Juridical Data Research, DI 201B and D1 201C.

10) Bookkeeping of Rights

Land parcels whose rights have been assigned through affirmation of conversion, recognition of rights and stipulation of decisions of rights givers, are then recorded in accordance with the objects of land parcels such as Property Rights, Building Use Rights, Use Rights and / or waqf in the land book signed by the Chair of the Adjudication Committee on behalf of Head of the Land Office of each district. 
11) Issuance of Certificate of Land Rights

Issuance of certificates by the Land Office of Bondowoso Regency, Jember Regency, Situbondo Regency and Banyuwangi Regency is submitted directly, if the data from the PTSL participants is complete and there are no disputes. The handover of the certificate is directly handed over to the right holder without a set schedule or target.

12) Documenting and submitting the results of activities

In carrying out the documentation and submission of activity results, the PTSL Adjudication Committee for Bondowoso Regency, Jember Regency, Situbondo Regency and Banyuwangi Regency carried out the collection, grouping, processing and storage of PTSL data in the form of juridical documents and physical data, as well as other files based on the results of each stage carried out. by the Bondowoso Regency Land Office. After all the data is stored and archived, then the Head of the PTSL Adjudication Committee of each Regency submits the results of the PTSL activities to the Head of the Land Office which is made in the form of an Official Report on the Handover of files and documents from the results of PTSL activities signed by the Chairman of the PTSL Adjudication Committee and the Head of the Land Office in each district.

\section{3) Reporting}

At this stage it can be seen whether the PTSL program in that year can run smoothly or there are problems that occur during the PTSL program, so that it can be used as evaluation material so that the PTSL Program in the following year can run better.

\subsection{Analysis of Obstacles and Efforts of the Land Office in Implementing a Complete} Systematic Land Registration program in Bondowoso Regency, Situbondo Regency, Jember Regency, and Banyuwangi Regency

To analyze the constraints that occurred in the implementation of PTSL in 4 (four) Land Offices of the Ex-Besuki Regency, researchers used a SWOT analyst.This analysis is based on the relationship or interaction between internal elements, namely strengths and weaknesses, to external elements, namely opportunities and threats are identified as external factors. ${ }^{4}$

1) Strength

The implementation of PTSL in Bondowoso Regency, Jember Regency, Situbondo Regency and Banyuwangi Regency is carried out based on the Standard Operating Procedure (SOP) that has been established by the government in Ministerial Regulation Number 6 of 2018 concerning Systematic land registration, in this Regulation it has been explained in full regarding the stages PTSL implementation activities starting from the beginning to the end of PTSL activities. As well as PTSL financing has been budgeted based on the DIPA of each district. The Jember Regency Land Office determines the amount of PTSL fees that will be charged to the community based on Regent Regulation Number 6 of 2018 concerning Charging of Financing Preparation for Complete Systematic land registration. Likewise, the Land Office of Banyuwangi Regency, stipulates PTSL fees based on Regent Regulation Number 11 of 2018 concerning Financing for Preparation of Complete Systematic land registration which is borne by the community.

In addition to the establishment of SOP and Regent Regulations, prior to the implementation of PTSL the Land Office of each district conducted outreach to the community about PTSL. The implementation of the socialization carried out by the Land

\footnotetext{
${ }^{4}$ Irham Fahmi, Manajemen Strategis, CV Alfabeta, Bandung 2015, hlm. 252
} 
Office of Situbondo Regency was carried out in the year before the PTSL was carried out with the aim of providing understanding to the community so that the community had prepared the PTSL registration requirements, besides that it was also to find out existing problems so that these problems could be resolved first.

The implementation of PTSL activities is also equipped with the necessary facilities and infrastructure during the activity process. includes a map of the registration list in the form of a line map, photo map, work map containing mapping of land parcels that have been registered for rights. Other advantages or strengths of the Banyuwangi Regency Land Office are having good quality Human Resources capabilities, careful planning, and a community enthusiastic about the PTSL program which was proven in 2018 the Banyuwangi Regency Land Office received the $2^{\text {nd }}$ (two) National level nomination for the PTSL program.

\section{2) Weaknesses}

The weaknesses that occur in the Land Office of Bondowoso Regency and Jember Regency include the low quality of Human Resources (Committee and Task Force) due to frequent mistakes during activities. In addition, the lack of human resources at the Bondowoso and Banyuwangi Land Offices is due to the increasing number of targets each year. Lack of communication between the PTSL Committee at the Bondowoso and Jember Regency Land Offices and the PTSL Committee in each village has resulted in a misunderstanding of the information received. The absence of regulations from the District Heads of Bondowoso and Situbondo Regencies regarding PTSL financing for the community, causing several Village Heads to charge more than IDR 150,000.

\section{3) Opportunities}

The progress of PTSL activities has a chance to be successful and successful because there is a level of community expectation that the PTSL program can provide benefits to the community and make it easier for the community to obtain certificates which is quite high even though there are some people with low levels of awareness. In addition, the support from the government and local law enforcement officials in the 4 (four) former Besuki districts can also support the success of the PTSL program. Also, equipped with the development of facilities and infrastructure each year makes it easier for the process at each stage of the PTSL to run smoothly.

\section{4) Threats}

The low level of public awareness of the importance of legal certainty over ownership of land rights in the form of land certificates in Bondowoso, Jember, and Situbondo districts is still low. Some communities are reluctant to participate and do not believe in the activities of PTSL, and they feel they cannot afford to pay PTSL costs, which they feel are still expensive. This is evidenced by the findings of several communities who did not complete their juridical data requirements on the grounds that they were still outside the city, or even rejected outright because they thought land certificates were not important, thus hampering the process of issuing land certificates.

There are several persons who are not responsible for illegal collection of PTSL fees that is not in accordance with the provisions of SKB 3 of the Minister (Surat Keputusan Bersama Menteri) Number 34 of 2017 concerning Systematic Land Registration Financing. The success of an activity or program can be seen from several factors. 
According to Soerjono Soekanto, whether it is effective or not a law is determined by 5 (five) factors, namely: ${ }^{5}$

a. His own legal factor (Law)

An activity will run well if there are regulations governing the activity. These regulations are useful as guidelines and references in every stage of a program. In this Complete Systematic Land Registration (PTSL) program, the government, especially the Ministry of Agrarian Affairs, makes a regulation on Complete Systematic Land Registration. The Land Office of Bondowoso Regency, Banyuwangi Regency, Jember Regency and Situbondo Regency in implementing the PTSL program is based on Ministerial Regulation Number 6 of 2018 concerning Systematic land registration, Joint Decree (SKB) 3 of the Minister Number 34 of 2017 concerning Financing for Systematic land registration preparation. Jember Regent Regulation Number 6 of 2018 concerning Charging of Financing Preparation for Complete Systematic land registration, and the Regional Government of Banyuwangi Regency also forming Banyuwangi Regent Regulation Number 11 of 2018 Financing Preparation for Complete Systematic land registration charged to the community.

b. Law enforcement factors, namely the parties who create and apply the law

Law enforcers, namely the parties who apply the law, in this study are the Human Resources of the Former Besuki Land Office who are the PTSL team. An activity can run effectively if the resources that are part of an activity have good quality and understanding of each activity. In practice PTSL which has been implemented from 2017 to 2019, it can be said that many teams do not understand and master the implementation of PTSL program in Bondowoso Regency, Jember Regency, Situbondo Regency and Banyuwangi Regency, so that resulting in errors in filling in juridical, physical, and administrative data. Lack of communication between the Land Office PTSL team and the village PTSL team causes miscommunication (misunderstanding), Lack of quantity of Human Resources when the number of targets increases has an effect on the implementation of PTSL.

c. Facility factors or facilities that support law enforcement

The facility or facility factor is a necessary factor in supporting the PTSL program, because even though Human Resources are good in quality and quantity, without supporting facilities (facilities and infrastructure), the implementation of the PTSL program will not be successful. The implementation of the PTSL program in Bondowoso Regency, Jember Regency, Situbondo Regency and Banyuwangi Regency in terms of facilities and infrastructure that support law enforcement is running effectively because the facilities and infrastructure in each PTSL village are very supportive. The Land Office provides equipment and tools in the form of land measurement tools, office stationery (ATK), printers, ink, HVS paper.

$\mathrm{d}$. The public factor, which is the environment where the law applies or is applied

The community has a very important role in implementing the PTSL program. Effective or not PTSL activities depend on the level of awareness of the community itself. The targets of PTSL are people who have not registered their land rights, and people who already have certificates in order to improve the quality of land registration data. In research in the area of the Former Besuki Residency, the interest and expectation of the community towards the Land Office of the Former Besuki Residence is very large,It is proven that the target of issuing certificates every year has increased, but there are people, especially the middle to lower class, who feel it is difficult to pay

\footnotetext{
${ }^{5}$ Soerjono Soekanto, Faktor-Faktor yang Mempengaruhi Penegakan Hukum, PT. Raja Grafindo Persada, Jakarta, 2008, hlm. 8
} 
the costs for land registration, and do not believe in the PTSL program implemented by the Land Office of the Ex Keresidenan Besuki area, this is due to several reasons, right holders have registered their land independently (sporadically) and / or in a program PRONA (National Agrarian Operation Project), but for several years the certificate has not been completed.

e. Factors of culture, which are the results of works, creations, and feelings that are affected by the audience

Cultural factors that occur in society are factors that affect the effectiveness or failure of a program or activity to be carried out. Cultural factors are directly related to the mindset of the people themselves. The community does not understand the importance of land registration to provide legal certainty for the land they occupy or they own. The community still believes that the sale and purchase agreement of a plot of land with a statement letter signed on a stamp duty can have absolute legal force, there are even people who carry out legal processes only verbally.

\section{Conclusion}

1. Implementation of the Complete Systematic Land Registration Program (PTSL) in Bondowoso Regency, Jember Regency, Situbondo Regency, and BAnyuwangi Regency in terms of legal factors is running effectively due to the existence of Ministerial Regulation Number 6 of 2018 concerning Systematic land registration, Joint Ministerial Decree (SKB) 3 Number 34 of 2017 concerning Financing for Preparation of Systematic land registration, and Regents' Statements issued by the Regents of Jember and Banyuwangi.

2. The implementation of the Complete Systematic Land Registration Program (PTSL) in Bondowoso Regency, Jember Regency, Situbondo Regency and Banyuwangi Regency in terms of law enforcement factors (Human Resources) was less effective. This is evidenced by the existence of several Committees and Task Forces that experienced errors in filling in juridical data, physical data, and administration, besides that the lack of communication between the committees led to misunderstanding of information about PTSL activities.

3. Implementation of the Complete Systematic land registration program in Bondowoso Regency, Jember Regency, Situbondo Regency and Banyuwangi Regency in terms of facilities and infrastructure that support law enforcement is running effectively because the facilities and infrastructure in each PTSL village are very supportive.

4. Implementasi Program land registration Sistematis Lengkap (PTSL) di Kabupaten Bondowoso, Kabupaten Jember, Kabupaten Situbondo, dan Kabupaten Banyuwangi dari segi Faktor masyarakat kurang efektif dikarenakan terdapat masayarakat yang enggan untuk ikut kegitan PTSL ini karena biaya yang terlalu mahal sehingga mereka tidak mampu untuk membayar biaya pendaftaran. Selain itu, tingkat kepercayaan masyarakat yang rendah terhadap program PTSL.

5. Implementation of the Complete Systematic Land Registration Program (PTSL) in Bondowoso Regency, Jember Regency, Situbondo Regency, and Banyuwangi Regency in terms of community factors has been ineffective because there are village people who think that the sale and purchase agreement of a plot of land with a statement letter signed on a stamp duty is already can have absolute legal force, there are even people who carry out legal processes only verbally. 


\section{References}

Andi Sapto Haryoko, S.H. Wawancara Kantor Pertanahan Kabupaten Bondowoso, (01 September 2020) Pada pukul 09.00 WIB.

Andrianih, Aan, Efektivitas Undang-Undang Nomor 1 Tahun 1965 tentang Pencegahan Penyalahgunaan dan/atau Penodaan Agama terhadap Kerukunan Beragama, Jakarta, Tesis FH UI, 2012

Amiruddin. 2006. Pengantar Metode Penilitian Hukum. Jakarta: PT Raja Grafindo Persada

Adi, Rianto.2010.Metode Penilitian Sosial dan Hukum. Jakarta. Granit

Erlies Septiana Nurbandi dan Salim, H.S. 2013. Penerapan Teori Hukum Pada Penilitian Tesis dan Disertasi.Jakarta: Rajawali Pers

Fahmi Irham.2015. Manajemen Strategis, CV Alfabeta, Bandung 2015, hlm. 252

Harsono, Boedi.2013.Hukum Agraria IndonesiaSejarah Pembentukan Undang-Undang Pokok Agraria, Isi dan pelaksanaanya.Jakarta: Universitas Trisakti

Herdiansyah, Haris.2010.Metode Penilitian Kualitatif.Jakarta: Salemba Humanika

Isnaini, et al (2020). The Models of North Sumatra Provincial Government Policy in Resolving the Ex-Hgu Land Conflicts of PTPN II Plantations in Deli Serdang Regency. Budapest International Research and Critics Institute-Journal (BIRCIJournal). P. 1206-1215.

Johnny Ibrahim dan Jonaedi Efendi.2016.Metode Penilitian Hukum Normatif dan Empiris.Depok: Prenadamedia Group

Jhonny S.H., Wawancara Kantor Pertanahan Kabupaten Situbondo (27 Agustus 2020), Pada pukul 09.00 WIB

Kholil, S., et al. (2019). Communication Planning of Langsa City Government in Building an Islamic and Environmentally Friendly City. Budapest International Research and Critics Institute-Journal (BIRCI-Journal), 638-644.

Mardi Siswoyo, A.Ptnh, M.M. Wawancara Kantor Pertanahan Kabupaten Jember (25 September 2020) Pada pukul 08.00 WIB

Maskury S.H., Wawancara Kantor Pertanahan Kabupaten Banyuwangi (3 September 2020), pada pukul 15.00

Perdana, A. A., et al. (2019). Society Response to Mobile Services on Mobile on The Road Investment Services and Integrated One-Stop Licensing Services in Tebing Tinggi City. Britain International of Humanties and Social Sciences (BIoHS) Journal, 44-52.

Peraturan Pemerintah Republik Indonesia Nomor 10 Tahun 1961 tentang pendaftaran tanah

Peraturan Pemerintah Republik Indonesia Nomor 24 tahun 1997 tentang pendaftaran tanah

Peraturan Menteri Agraria dan Tata Ruang/Kepala Badan Pertanahan Nasional Republik Indonesia Nomor 6 Tahun 2018 tentang Pendaftaran Tanah Sistematis Lengkap

Soekanto, Soerjono.1983.Penegakan Hukum.Bandung: Bina Cipta

2008. Faktor-Faktor yang Mempengaruhi Penegakan Hukum. Jakarta: PT. Raja Grafindo Persada

Undang-Undang Dasar Negara Republik Indonesia Tahun 1945

Undang-Undang nomor 5 Tahun 1960 tentang Peraturan Dasar Pokok-Pokok Agraria 